pathology Research Unit, will be jointly in charge of Shell Research's new Chemical Enzymology Unit. They will be assisted by Dr. Rita Cornforth, wife of Dr. John Cornforth, and a group of experienced biochemists and technical assistants. The Unit will have a new laboratory at Sittingbourne, in Kent (due for completion in April 1963). Its work will embrace both basic research and research on topics of shorter-range interest-mainly in the sphere of 'biological chemistry', on which Shell Research largely relies in the development of pesticides and herbicides.

\section{Babcock and Wilcox Nuclear Development Center: Dr. W. M. Breazeale}

Dr. Wrlliam M. Breazeale, a nuclear scientist who holds the first reactor operator's licence issued by the U.S. Atomic Energy Commission, has been appointed director of the Babcock and Wilcox Co. Nuclear Development Center. Comprising a 3.5 million dollar test reactor and nuclear fuel laboratory, now under construction, and an existing critical experiment laboratory, the Center is being established near Lynchburg, Va. Dr. Breazeale will be responsible for providing laboratory and experimental support to the Atomic Energy Division, which has overall responsibility for the Company's nuclear power business. Joining Babcock and Wilcox Co. in 1956 as assistant manager in the Atomic Energy Division's Nuclear Engineering Department, Dr. Breazeale became assistant manager of the Project Management Department in 1959, and in 1960 was made senior technical adviser for the Division. Dr. Breazeale received his first degree from Rutgers and later took his Ph.D. degree in physies at the University of Virginia at Charlottesville.

\section{International Academy of Astronautics:}

Corresponding Members

The following have been elected corresponding members of the International Academy of Astronautics of the International Astronautical Federation.

Basic Sciences Section: Prof. Edoardo Amaldi, Istituto Física Universitá, Rome; Prof. K. O. Kiepenheuer, Fraunhofer Institut, Freiburg i/B.; Prof. S. K. Mitra, national research professor, Institute of Radio Physics and Electronics, Calcutta; Dr. Svein Rosseland, Institute of Theoretical Astrophysies, Oslo University, Blindern; Dr. Harry Wexler (now deceased), U.S. Weather Bureau, Washington, D.C. ; Dr. John R. Winckler, professor of physics, Institute of Technology, University of Minnesota, Minneapolis.

Engineering Sciences Section: Dr. Sydney Goldstein, Harvard University, Cambridge, Mass.; Dr. William R. Hawthorne, Engineering Laboratory, Cambridge, England; Dr. Hideo Itokawa, Institute of Industrial Science, University of Tokyo; Dr. W. F. Klemperer, Douglas Aircraft Co., Santa Monica, Cal.; Dr. Hans W. Liepmann, California Institute of Technology, Pasadena, Cal.; Mr. George P. Sutton, manager, Long Range Planning, Rocketdyne, Canoga Park; Dr. Herbert York, chancellor, University of California at San Diego, Cal.; Mr. M. J. Zucrow, Jet Propulsion Center, Purdue University, Lafayette, Indiana.

Life Sciences Section: Dr. Pierre Biget, Centro d'Enseignement et de Recherches de Médecine Aéronautique, Paris; Dr. E. O. Errebo-Knudsen, Institute of Aviation Medicine, Copenhagen; Dr. O. H. Gauer, Freien Universität, Berlin; Dr. C. J.
Lambertsen, University of Pennsylvania, Philadelphia; Mr. Alfred M. Mayo, manager, Advanced Systems Department, Astronautics Division, Chance Vought Corp., Dallas, Texas; Dr. Hermann Rahn, Department of Physiology, University of Buffalo, N.Y.; Dr. Cornelius A. Tobias, Donner Laboratory, University of California, Berkeley; Dr. F. M. Violette, Centre d'Enseignement et de Recherches de Médecine Aéronautique, Paris; Lt.-Col. Stanley C. White, Life Science Division, National Aeronautics and Space Administration, Langley Air Force Base.

The Academy now has a total membership of 140 , from 22 countries. The second meeting of the officers and trustees of the Academy will be held during the Thirteenth Congress of the International Astronautical Federation at Varna, Bulgaria, on September 25 .

\section{Employment of Graduates}

THE sixteenth a nnual report of the University of Durham Appointments Board covering the academic year 1960-61 records that the demand for mathematicians continued to mount faster than supply, and that the similar position with physicists also worsened (Pp. 12. Durham: The University Appointments Board, 1962). On the other hand, the demand for chemists eased and the supply of chemical engineers began to catch up with demand; but while there were very few vacancies for geologists, especially in industry, the shortages of good mechanical and electrical engineers remained chronic. Demand for arts graduates from all employers remained good, and more women found jobs in the chemical and allied industries, mainly in consumer research and information work. The nationalized industries remained unpopular, but as a whole the public service gained more recruits, especially in central government departments; local government had little attraction. Competition for the most outstanding engineers, scientists and arts graduates intensified, whereas the least-able and least-effective had more difficulty in locating suitable employment. Grave concern is expressed over the numbers entering the teaching profession: in arts and science alike there was a distinct drop in the numbers of both men and women going on to train as teachers, and the numbers of women science graduates and of men arts graduates taking up teaching posts untrained also decreased. Comment is made on the ineffective character and handling of recruitment literature, the doubling of the number of men entering the private sector of employment, and the quadrupling of the number of men entering public service.

\section{The Australian Society of Limnology}

Ar a meeting held at Monash University on May 26 a constitution was drawn up for an Australian Society of Limnology. The objectives of the Society will be: "To establish effective liaison between all persons interested in any aspect of fresh and brackish water research in Australia, and to promote the study of and encourage these interests in State and Commonwealth Research Institutes and Departments, and educational Institutions". The means of attaining these objectives will be: " $(a)$ The establishment and maintenance of a register of all persons working in appropriate fields in Australia and adjoining countries, giving details of their current interests and relevant publications; (b) The holding of an annual congress which will coincide with the annual general meeting; (c) The production of a Newsletter by an 